\title{
Science Teacher Confidence
}

\author{
Megan Kolby Noble \\ Somerset County Public Schools, Princess Anne, US
}

Email address:

knoble@somerset.k12.md.us

\section{To cite this article:}

Megan Kolby Noble. Science Teacher Confidence. Science Journal of Education. Vol. 4, No. 1, 2016, pp. 9-13.

doi: 10.11648/j.sjedu.20160401.12

\begin{abstract}
The aim of this study was to determine if in-service teachers had similar anxiety to that of pre-service teachers, if the anxiety they felt towards teaching science could be attributed to similar factors as those that can predict anxiety in preservice teachers, and whether teachers felt as though they were given opportunities to become more confident teachers. A survey was given to 48 science teachers in Somerset County, where $65 \%$ of those teachers participated. After reviewing survey responses, it can be concluded that while the majority of in-service teachers in Somerset County feel confident in their ability to teach science, they were less prepared, in the way research suggests is necessary, to teach science confidently. The study discusses possible reasons for heightened confidence and suggestions to further increase teacher confidence.
\end{abstract}

Keywords: Science, Anxiety, Confidence, in-service, Teaching

\section{Introduction}

Many science teachers enter the teaching profession with anxiety that can lead to low confidence in teaching science. While studies show that there are various factors that predict pre-service teacher anxiety toward teaching science, there has been little research done on the anxiety of in-service teachers (as cited by Friedrichsen \& Dana, 2003, 2005; Greenwood, 2003; Tanaquer, V., Novodvorsky, I., \& Tomanek, D.). Since teacher training and preparation in science education closely determine student achievement in science (Wenglinsky \& Silverstein, 2007), it is important for educators and school leaders to make sure the teachers they employ are prepared to step into the science classroom.

\section{Literature Review}

There are various factors that predict pre-service teacher anxiety toward teaching science, including low self-efficacy, limited science background knowledge, and a lack of strong role-models for teaching science (Yürük, 2011). Research has shown that student performance increases when teachers have less anxiety about teaching in general (Wenglinsky \& Silverstein and as cited in Koran \& Koran, 1981). While factors that influence pre-service teachers' anxiety have been identified, there has been little research done on anxiety that exists among in-service science teachers. If pre-service teachers have anxiety as they enter the profession, then more research needs to be done to determine whether that anxiety continues to exist as teachers start their careers and gain experience as science teachers.

In preparing to transition to the Next Generation Science Standards (NGSS), dramatic shifts need to take place in the science classroom. Rather than simply presenting information, teachers are going to need to encourage and support their students in developing their own explanations of science in developing solutions to science related problems (Krajcik, J., Codere, S., Dahsah, C., Bayer, R.,\& Mun, K., 2014). Teachers with anxiety towards teaching science will struggle to meet the rigorous demands of delivering the Next Generation Science Standards.

This study was guided by the following research questions, specifically to aid in preparing teachers to teach the NGSS: (1) Does science anxiety exist among in-service science teachers, (2) Are the factors that contribute to science anxiety in in-service teachers the same or similar to those of preservice teachers, and (3) Do in-service science teachers believe that their school system is taking steps to address science anxiety if it exists?

Three major variables can contribute to strengthening confidence in pre-service teachers. These variables include increasing subject matter knowledge (SMK), enhancing the preparation pre-service teachers receive, and engaging preservice teachers in various professional development opportunities to build confidence (Kenny, 2010; Kind, 2009; DeCoito, I.; Baxter, J. A., Ruzicka, A., Beghetto, R. A., \& 
Livelybrooks, D.). Kind implies that when pre-service teachers are given the chance to improve upon their SMK they are able to make substantial gains in their level of confidence. In order to obtain a higher level of SMK, Kind states that teachers and other school figures should work to obtain advice and suggestions from other colleagues with more experience with teaching science. In a study by Yürük (2011), pre-service teachers that took more science courses in college felt better prepared to teach science content and had higher levels of self-efficacy.

In sum, nearly all of the researchers and literature discuss the anxiety that exists among pre-service teachers, and possible solutions to reducing that anxiety. Where the literature is lacking, however, is the discussion of what happens once pre-service teachers with anxiety step into the science classroom. This research aims to determine whether or not anxiety exists among in-service teachers and if factors similar to those identified by pre-service teachers also plague in-service teachers. An anonymous survey will be conducted to determine teachers' perceived anxiety levels toward teaching science, whether they feel prepared to shift their teaching to deliver the NGSS, and whether teachers feel as though adequate professional development is being offered to aid in the reduction of anxiety and the preparation of delivering new science content.

\section{Methodology}

In the academic year 2015-2016, Somerset County implemented the NGSS. With this shift in education, science teacher preparation and confidence in teaching science through the new standards is an area of concern for many schools.

\subsection{Population and Sample}

There are four elementary schools in Somerset County, on Maryland's Eastern Shore, which serves a large population of students with low-socioeconomic status in a rural setting. Three out of the four elementary schools are Title One schools, all having a significant population of students from low-income families enrolled in these schools. To determine whether or not the science teachers in Somerset County have anxiety towards teaching science, 48 science teachers from grades Kindergarten to $5^{\text {th }}$ grade were sent a survey consisting of eight questions regarding their perceived confidence and factors that may contribute to anxiety. A random sample was not implemented in this study, causing possible weakness in the research.

\subsection{Instrument}

In this quantitative study a survey was issued to the 48 science teachers throughout Somerset County through Survey Monkey. The design was considered to be an explanatory study using descriptive statistics. This voluntary survey was made available to teachers for a three week period during April 2015. The confidentiality of responses was preserved since demographic information was not obtained and teachers were allowed to stop participating at any time. The instrument was considered valid since it was reviewed by experts from a committee from Salisbury University. In addition, the instrument was reviewed by Somerset County's Science Supervisor, who agreed that teachers would be able to answer the questions asked.

\subsection{Procedure}

Various factors have been identified as predictors of science teacher anxiety (Yürük, 2011) and these factors were considered in the survey sent to 48 science teachers in Somerset County. Teachers were questioned about their confidence in teaching science as well as their past experiences and background with science. Studies reviewed by the researcher also indicated that strong mentor teachers (Kenny, 2010) and professional development opportunities help reduce teacher anxiety (Baxter, Ruzicka, Beghetto, and Livelybrooks, 2013). Teachers were asked whether or not they felt as though Somerset County offered meaningful professional development opportunities. They were also asked whether or not they had opportunities to work with mentor science teachers who had strong background knowledge and no science teaching anxiety.

Teachers were sent a link to the survey through email containing a confidentiality statement. Administrators as well as the county science supervisor were made aware that the survey had been issued to science teachers.

\section{Results}

In transitioning to the Next Generation Science Standards, I feel confident in my ability to deliver hands-on learning experiences for my students on a consistent basis.

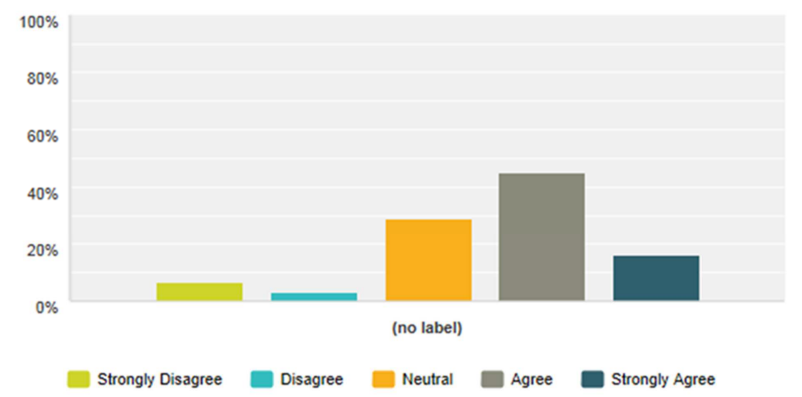

Figure 1. Results from survey on teachers' confidence in teaching hands-on learning experiences to students.

Of the 48 teachers from Somerset County who were sent the link to the Science Teacher Confidence Survey, 31 teachers $(65 \%)$ participated. In determining whether science teacher anxiety exists in Somerset County, participating teachers were asked whether they felt confident in their ability to deliver hands-on learning experiences for students on a consistent basis. Sixty-one percent of teachers either agreed or strongly agreed that they felt confident, while about $10 \%$ disagreed or strongly disagreed that they felt confident, and $29 \%$ were neutral. 
Based on research from Yürük (2011), three questions were asked in correlation with teacher confidence, including experiences as a student of science, experiences as a college level student in science, and overall science background knowledge. While $35 \%$ of teachers agreed or strongly agreed they had positive experiences with science teachers before entering college, $16 \%$ disagreed or strongly disagreed, and $48 \%$ responded as neutral. More than half of teachers $(55 \%)$ said they participated in college classes that prepared them to teach science with a hands-on approach, while 32\% disagreed or strongly disagreed, and $13 \%$ responded as neutral. In terms of strong science background knowledge, less than half the teachers (42\%) agreed or strongly agreed that their background knowledge was strong, 19\% disagreed or strongly disagreed, and 39\% responded as neutral.

Table 1. Survey Questions.

\begin{tabular}{|c|c|c|c|c|c|}
\hline $\begin{array}{l}\text { Survey } \\
\text { Question }\end{array}$ & $\begin{array}{l}\text { Strongly } \\
\text { Disagree }\end{array}$ & Disagree & Neutral & Agree & $\begin{array}{l}\text { Strongly } \\
\text { Agree }\end{array}$ \\
\hline \multirow{2}{*}{$\begin{array}{l}\text { Confidence in } \\
\text { teaching } \\
\text { science }\end{array}$} & $6.25 \%$ & $3.23 \%$ & $29.03 \%$ & $45.16 \%$ & $16.13 \%$ \\
\hline & 2 & 1 & 9 & 14 & 5 \\
\hline $\begin{array}{l}\text { Teacher self- } \\
\text { efficacy will }\end{array}$ & $0.00 \%$ & $0.00 \%$ & $9.68 \%$ & $67.74 \%$ & $22.58 \%$ \\
\hline $\begin{array}{l}\text { affect student } \\
\text { performance }\end{array}$ & 0 & 0 & 3 & 21 & 7 \\
\hline $\begin{array}{l}\text { Positive } \\
\text { experiences as }\end{array}$ & $0.00 \%$ & $16.13 \%$ & $48.39 \%$ & $29.03 \%$ & $6.45 \%$ \\
\hline $\begin{array}{l}\text { students of } \\
\text { science before } \\
\text { college }\end{array}$ & 0 & 5 & 15 & 9 & 2 \\
\hline $\begin{array}{l}\text { Participation } \\
\text { in college } \\
\text { science }\end{array}$ & $6.45 \%$ & $25.81 \%$ & $12.90 \%$ & $38.71 \%$ & $16.13 \%$ \\
\hline $\begin{array}{l}\text { courses in } \\
\text { preparation to } \\
\text { teach science }\end{array}$ & 2 & 8 & 4 & 12 & 5 \\
\hline $\begin{array}{l}\text { Overall } \\
\text { science }\end{array}$ & $6.45 \%$ & $12.90 \%$ & $38.71 \%$ & $38.71 \%$ & $3.23 \%$ \\
\hline $\begin{array}{l}\text { background } \\
\text { knowledge is } \\
\text { strong }\end{array}$ & 2 & 4 & 12 & 12 & 1 \\
\hline $\begin{array}{l}\text { Work with or } \\
\text { alongside }\end{array}$ & $3.23 \%$ & $16.13 \%$ & $35.48 \%$ & $35.48 \%$ & $9.68 \%$ \\
\hline $\begin{array}{l}\text { confident } \\
\text { mentor } \\
\text { teachers }\end{array}$ & 1 & 5 & 11 & 11 & 3 \\
\hline $\begin{array}{l}\text { School offers } \\
\text { opportunities } \\
\text { to become }\end{array}$ & $6.67 \%$ & $30.00 \%$ & $20.00 \%$ & $33.33 \%$ & $10.00 \%$ \\
\hline $\begin{array}{l}\text { more } \\
\text { confident in } \\
\text { teaching } \\
\text { science }\end{array}$ & 2 & 9 & 6 & 10 & 4 \\
\hline $\begin{array}{l}\text { County offers } \\
\text { opportunities } \\
\text { to become }\end{array}$ & $3.33 \%$ & $23.33 \%$ & $13.33 \%$ & $56.67 \%$ & $3.33 \%$ \\
\hline $\begin{array}{l}\text { more } \\
\text { confident in } \\
\text { teaching } \\
\text { science }\end{array}$ & 1 & 7 & 4 & 17 & 1 \\
\hline
\end{tabular}

Research by Luft (2009) and Kenny (2010) suggests that pairing teachers with confident mentor teachers can help reduce anxiety and increase teacher confidence. Teachers were asked whether they had opportunities to work with or alongside confident mentor teachers to aide in the delivery of hands-on science lessons. In response, $45 \%$ of teachers agreed or strongly agreed they did work with confident mentor teachers, 19\% disagreed or strongly disagreed, and $35 \%$ indicated neutral to working with confident mentor teachers.

The last three questions on the survey were asked to identify whether or not science teachers in Somerset County felt supported in teaching science, and whether they believed their own self-efficacy in teaching science affected student performance. Forty-three percent of teachers agreed or strongly agreed that their school offered opportunities to become a more confident science teacher, while $37 \%$ disagreed or strongly disagreed, and $20 \%$ responded as neutral. Sixty percent of teachers believe Somerset County offers opportunities to become more confident in teaching science, while $27 \%$ disagreed or strongly disagreed, and $13 \%$ responded as neutral. Finally, regardless of past experiences, current teaching confidence, or background knowledge, $90 \%$ of teachers agreed that their self-efficacy in teaching science with a hands-on approach will affect student performance. No teachers disagreed with this statement, and $10 \%$ responded as neutral.

\section{Discussion}

Teacher self-confidence is closely related to the amount of anxiety a teacher feels (Murphy, C., Neil, P., \& Beggs, J., 2007). This study determined whether or not in-service teachers had similar anxiety to that of pre-service teachers, whether or not the anxiety they felt towards teaching science could be attributed to similar factors as those that can predict anxiety in pre-service teachers, and whether teachers felt as though they were given opportunities to become more confident teachers.

In Somerset County the majority of the science teachers who participated in the study indicated they were confident in their ability to teach science. Since teacher confidence can affect student performance, it is important that teachers are confident in their ability to teach so that students can be successful. Since $30 \%$ of teachers neither agreed nor disagreed that they were confident to teach science it is hard to say whether those teachers are positively or negatively affecting student performance. Wenglinsky and Silverstein (2007) point out that student performance increases when teachers have less anxiety. If teachers do not feel confident in their ability to teach science, student performance could suffer.

The majority of science teachers agreed that their selfefficacy in teaching science will affect student performance. Wenglinsky and Silverstein (2007) indicate that there is a direct correlation between teacher preparation and teacher self-efficacy. While nearly all teachers agree that their selfefficacy will affect the performance of the students they teach, fewer teachers indicated that they were prepared, in the same way that research suggests is necessary for pre- 
service teachers (Kenny, 2010 \& Yürük, 2011), to teach science effectively. Having high self-efficacy, participating in classes both before and during college that prepare teachers to teach science, and having strong science background knowledge or PCK are all important factors in developing teachers who are highly qualified to teach science (Wenglinsky \& Silverstein, 2007). Based on these three factors, more than half the teachers seem to have high selfefficacy, but fewer teachers $(50 \%)$ indicated they participated in positive learning experiences to prepare them to teach science, and only $40 \%$ indicate their science background knowledge is strong. Yürük (2011) indicated that pre-service teachers who took more science courses in college felt better prepared to teach science content and had overall higher selfefficacy. If only half of the science teachers took classes in college to prepare them to teach, it would seem that only about half would have high self-efficacy. Not having strong background knowledge is a concern, because research (Murphy et al, 2007) suggests that when teachers have a lack of knowledge for the topics they teach, they are less likely to successfully engage students. The number of teachers who feel they have high background knowledge is considerably lower than the number of teachers who indicate they are confident to teach science in a hands-on and engaging way.

Research supports professional development and opportunities to work with confident mentor teachers as a way to build science teacher confidence and reduce anxiety (Baxter et al, 2013, Kind, 2009, and Kenny, 2010). Less than half (45\%) of the teachers indicate they have opportunities to work with confident mentor teachers and $35 \%$ responded as neutral to working with confident mentor teachers. It could be that the teachers who responded as neutral are not able to work with these mentors on a consistent basis, or might not feel the need to work with them at all. In terms of enhancing their own PCK, only $43 \%$ of teachers indicated that their school offered opportunities to become more confident science teachers, while $60 \%$ said they felt the county offered opportunities to become more confident science teachers. If many teachers feel as though they are not able to work with confident mentor teachers, and have little opportunity to become more confident teachers within their own schools, it could be that so many teachers feel confident in teaching science due to their own self-regulated learning. A study by Taylor and Corrigan (2005) identified a program in which teachers educated themselves to improve on their content knowledge to raise self-confidence. The problem with the study was that teachers reported feeling more confident to teach science but did not demonstrate an increase their content knowledge. Similar results could be happening in this study. If teachers are engaging in selfregulated learning and report feeling confident to teach science, how is it that they are reporting a lack of strong science background knowledge?

\section{Limitations}

A strength of this study is the high number of participants. Sixty-five percent of teachers in the county responded to the survey, aiding in the validity of results. A weakness of the study was the high number of 'neutral' responses to many of the questions. Assumptions had to be made based on prior research as to why teachers might have responded that way. Another weakness of the study could be that it was not feasible to get demographic information from teachers, such as number of years teaching, without being able to identify teachers. Teachers' years of experience might contribute to higher or lower confidence.

\section{Conclusions}

Another researcher might want to conduct more research to better understand the discrepancy between science background knowledge and confidence. According to research about science teacher anxiety, in order for teachers to have high self-efficacy for teaching science they should also have overall strong background knowledge. Since there were considerably fewer teachers who reported having overall strong background knowledge in science but high confidence for teaching, it may be helpful for another researcher to conduct classroom observations to better understand what goes on during science instruction. It might also be helpful to interview science teachers and conduct more qualitative research to understand their thoughts and perceptions about their confidence to teach science.

\section{References}

[1] Baxter, J. A., Ruzicka, A., Beghetto, R. A., and Livelybrooks, D. (2013) Professional development strategically connecting mathematics and science: The impact on teachers' confidence and practice. School Science and Mathematics, 114 (3), 102113.

[2] DeCoito, I. (2006). Innovations in science education: Challenging and changing teachers' roles and beliefs. Canadian Journal of Science, Mathematics, and Technology Education, 6 (4), 339-350.

[3] Greenwood, A. M. (2003). Factors influencing the development of career-change teachers' science teaching orientation. Journal of Science Teacher Education, 14, 217-234.

[4] Kind, Vanessa (2009). A conflict in your head: An exploration of trainee science teachers' subject matter knowledge development and its impact on teacher self-confidence. International Journal of Science Education, 31 (11), 1529-1562.

[5] Kenny, John (2010). Preparing pre-service primary teachers to teach primary science: A partnership-based approach. International Journal of Science Education, 32 (10), 12671288.

[6] Krajcik, J., Codere, S., Dahsah, C., Bayer, R., and Mun, K. (2014) Planning instruction to meet the intent of the next generation science standards. Journal of Science Teacher Education, 25, 157-175.

[7] Luft, Julie A. (2009). Beginning secondary science teachers in different induction programmes: The first year of teaching. International Journal of Science Education, 31 (17), 23552384. 
[8] Murphy, C., Neil, P., \& Beggs, J. (2007). Primary science teacher confidence revisited: Ten years on. Educational Research, 49 (4), 415-430.

[9] Tanaquer, v., Novodvorsky, I., and Tomanek, D. (2010). Factors influencing entering teacher candidates' preferences for instructional activities: A glimpse into their orientations towards teaching. International Journal of Science Education, 32 (10), 1389-1406.

[10] Taylor, N. and Corrigan, G. (2005). Empowerment and confidence: pre-service teachers learning to teach science through a program of self-regulated learning. Canadian
Journal of Science, Mathematics, and Technology Education, $5(1), 43-60$.

[11] Wenglinsky, H. and Silverstein, S. C. (2007). The Science Training. Association for Supervision and Curriculum Development, 24-29.

[12] Yürük, N. (2011). The predictors of preservice elementary teachers' anxiety about teaching science. Journal of Baltic Science Education, 10 (1), 17-26. 